\title{
ENZYMATIC AND HEMOLYTIC ACTIVITIES OF Candida dubliniensis STRAINS
}

\author{
Carlos Eduardo Blanco LINARES(1), Érico Silva de LORETO(1), Carolina Pereira SILVEIRA(1), Patrícia POZZATTI(1), Liliane Alves SCHEID(1),
} Janio M. SANTURIO(2) \& Sydney Hartz ALVES(2)

\begin{abstract}
SUMMARY
Candida dubliniensis is an opportunistic yeast that has been recovered from several body sites in many populations; it is most often recovered from the oral cavities of human immunodeficiency virus-infected patients. Although extensive studies on epidemiology and phylogeny of $C$. dubliniensis have been performed, little is known about virulence factors such as exoenzymatic and hemolytic activities. In this study we compared proteinase, hyaluronidase, chondroitin sulphatase and hemolytic activities in 18 C. dubliniensis and 30 C. albicans strains isolated from AIDS patients. C. albicans isolates produced higher amounts of proteinase than $C$. dubliniensis $(p<0.05)$. All the tested $C$. dubliniensis strains expressed hyaluronidase and chondroitin sulphatase activities, but none of them were significantly different from those observed with $C$. albicans $(p>0.05)$. Hemolytic activity was affected by $\mathrm{CaCl}_{2}$; when this component was absent, we did not notice any significant difference between $C$. albicans and $C$. dubliniensis hemolytic activities. On the contrary, when we added $2.5 \mathrm{~g} \% \mathrm{CaCl}_{2}$, the hemolytic activity was reduced on $C$. dubliniensis and stimulated on C. albicans tested strains $(p<0.05)$.
\end{abstract}

KEYWORDS: Candida dubliniensis; Proteinase; Hyaluronidase; Chondroitin sulphatase; Hemolytic activity.

\section{INTRODUCTION}

Candida dubliniensis has recently been added up to the growing list of potential opportunistic pathogen yeasts. This species shares many phenotypic characteristics with $C$. albicans, such as production of chlamydospores and germ tube ${ }^{17}$. The pathogenesis of diseases caused by this species is partially known and then, well-studied virulence factors in C. albicans must also be assessed in $C$. dubliniensis. In $C$. albicans the widely advocated virulence traits include dimorphism, adherence, enzyme production, rapid phenotypic switch, antigenic variation and other several immunoevasion mechanisms ${ }^{4}$. Regarding enzyme production, hydrolytic enzymes such as proteinase, phospholipase, hyaluronidase and chondroitin-sulphatase are putative virulence factors that help C. albicans to invade tissues ${ }^{4}$.

Secreted aspartic proteinases (Saps), encoded by the SAP gene family, appear to play a major role in $C$. albicans virulence ${ }^{7}$. Seven homologues genes $(S A P)$ were also detected in $C$. dubliniensis by Southern analysis ${ }^{5}$ but scarce studies were performed focusing proteinase activity in this species ${ }^{6,10}$. Hyaluronidase and chondroitinsulphatase are considered to be important virulence factors in oral bacteria that cause oral infectious diseases. SHIMIZU et al. ${ }^{15}$ were the first researchers that described these exoenzymes in Candida species; as far as we know, these enzymes have not yet been studied in $C$. dubliniensis isolates.
Hemolytic activity is another virulence factor exhibited by pathogenic microorganisms which permits growth in the host using several iron-binding proteins as a source of iron. Hemoglobin is an important iron-source for pathogenic microorganisms, and the hemolytic activity and the hemoglobin utilization have been considered as a pathogenic factor ${ }^{8,19}$. Studies to evaluate this virulence factor in $C$. dubliniensis have not been carried out yet.

The purpose of the present study was to determine whether there are differences in the expression of proteinase, hyaluronidase, chondroitin sulphatase and hemolytic activity between $C$. albicans and C. dubliniensis. The interference of $\mathrm{CaCl}_{2}$ in the hemolytic activity was also evaluated.

\section{MATERIAL AND METHODS}

Candida isolates: We have studied eighteen clinical strains of $C$. dubliniensis and thirty of $C$. albicans, both recovered from oral candidiasis of AIDS patients. Phenotypic identification tests of $C$. dubliniensis were confirmed by genotypic methods as randomly amplified polymorphic DNA (RAPD) using the primers CDU (5' GCGATCCCC3') ${ }^{17}$ and B-14 (5' GATCAAGTC3') $)^{2}$. C. albicans isolates were identified by classical methods ${ }^{11}$. All the cultures were maintained at $-80{ }^{\circ} \mathrm{C}$ as stock collection of Laboratório de Pesquisas Micológicas, Universidade Federal de Santa Maria, Rio Grande do Sul, Brazil. 


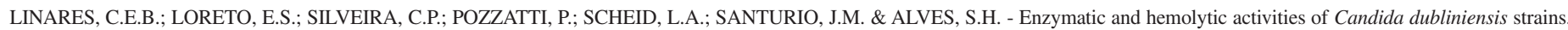
Rev. Inst. Med. trop. Med. S. Paulo, 49(4):203-206, 2007.

Table 1

Production of proteinase, hyaluronidase and chondroitin sulphatase by $C$. dubliniensis and C. albicans

\begin{tabular}{|c|c|c|c|}
\hline Species & Proteinase $(\mathrm{Pz})^{*}$ & Hyaluronidase $(\mathrm{Hz})^{*}$ & Condroitin sulphatase $(\mathrm{Cz})^{*}$ \\
\hline $\begin{array}{l}\text { C. dubliniensis } \\
(\mathrm{n}=18)\end{array}$ & $\begin{array}{l}0.61-0.84^{\mathrm{a}} \\
\text { mean }=0.75\end{array}$ & $\begin{array}{c}0.70-0.85^{\mathrm{c}} \\
\text { mean }=0.79\end{array}$ & $\begin{array}{c}0.55-0.81^{\mathrm{e}} \\
\text { mean }=0.72\end{array}$ \\
\hline $\begin{array}{l}\text { C. albicans } \\
(\mathrm{n}=30)\end{array}$ & $\begin{array}{c}0.60-0.79^{\mathrm{b}} \\
\text { mean }=0.68\end{array}$ & $\begin{array}{c}0.80-0.86^{\mathrm{d}} \\
\text { mean }=0.81\end{array}$ & $\begin{array}{c}0.60-0.92^{\mathrm{f}} \\
\text { mean }=0.78\end{array}$ \\
\hline
\end{tabular}

*Value obtained by dividing the diameter of the colony by the total diameter of the colony including precipitation or clear zone. a $<\mathrm{b}(p<0.02)$

Exoenzymes: The production of four functional enzyme categories by $C$. dubliniensis was investigated by employing the culture media and techniques as described in order to check the production of proteinase ${ }^{14}$, hyaluronidase and chondroitin sulphatase ${ }^{15}$ by $C$. albicans. Plates were incubated and readings were taken after $48 \mathrm{~h}$ at $37{ }^{\circ} \mathrm{C}$ for proteinase and after four days at $37^{\circ} \mathrm{C}$ for hyaluronidase and chondroitin sulphatase ${ }^{15}$. A clear zone around the colonies was considered to indicate proteinase, hyaluronidase and chondroitin sulphatase activities. Enzymatic activities of proteinase $(\mathrm{Pz})$, hyaluronidase $(\mathrm{Hz})$ and chondroitin sulphatase $(\mathrm{Cz})$ were measured by dividing the colony diameter by the clear or precipitation zone plus colony diameter. $C$. albicans CBS 2730, C. albicans 2630 and C. dubliniensis CBS 7987 were included as control.

Hemolytic activity ${ }^{8}:$ C. dubliniensis and C. albicans strains were streaked onto Sabouraud dextrose agar and incubated at $37{ }^{\circ} \mathrm{C}$ for 18 $\mathrm{h}$. The resulting cultures were harvested and washed with sterile saline, and yeast suspensions with an inoculum sized $1 \times 10^{8}$ cells $/ \mathrm{mL}$ were prepared using hemocytometric counts. Ten microliters of this suspension were spot on Sabouraud dextrose agar supplemented with $3 \%$ glucose and fresh sheep blood $(7 \%)$. Plates were incubated at $37^{\circ} \mathrm{C}$ in $5 \% \mathrm{CO}_{2}$ for $48 \mathrm{~h}$. The presence of a distinctive translucent halo around the inoculum site indicated positive hemolytic activity. The ratio obtained by dividing the diameter of the colony by the total diameter of the colony plus the translucent halo was used as a hemolytic index $(\mathrm{Hi})$ representing the intensity of the hemolysin production by C. dubliniensis and C. albicans.

Statistical analysis: enzymatic production and hemolytic activities in the two groups were compared by the Mann-Whitney test.

\section{RESULTS}

All analyzed strains showed proteinase, hyaluronidase and chondroitin sulphatase activities.

Proteinase activity of $C$. dubliniensis resulted in Pz range from 0.61 to $0.84($ mean $=0.75)$ and $0.60-0.79$ for $C$. albicans $($ mean $=$ $0.68)$; these differences were significant $(p<0.02)$ (Table 1$)$.

Hyaluronidase and chondroitin sulphatase activities in $C$. dubliniensis and $C$. albicans are shown in Table 1 and no statistical differences were detected when we compared both species.

In vitro hemolytic activities of $C$. dubliniensis, expressed as hemolysis index (Hi), changed from 0.55 (well-defined hemolysis zone) to 1.0 (absence of hemolytic activity). Only two C. dubliniensis isolates showed $\mathrm{Hi}=1.0$. In $C$. albicans, the $\mathrm{Hi}$ changed from 0.5 to 0.85 (Table 2). No significant differences were observed between both species $(p>0.05)$.

Adding $\mathrm{CaCl}_{2} 2.5 \%$ to Sabouraud glucose agar supplemented with sheep blood, the hemolytic activities declined in $C$. dubliniensis and rose in $C$. albicans. Hi in the $C$. albicans group, was significantly more expressive than that obtained for $C$. dubliniensis $(p<0.01)$. Furthermore, when we compared the $C$. albicans Hi between the results of the two media (with and without $\mathrm{CaCl}_{2}$ ), we detected hemolytic activity of $C$. albicans was better expressed by $\mathrm{CaCl}_{2}$ addition $(p<$ 0.01) (Table 2).

Table 2

Hemolyic activity of $C$. dubliniensis and C. albicans considering the effect of $\mathrm{CaCl}_{2}$

\begin{tabular}{lcc}
\hline Species & \multicolumn{2}{c}{ Hemolysis index (Hi)* } \\
& Without $\mathrm{CaCl}_{2}$ & With $2.5 \% \mathrm{CaCl}_{2}$ \\
\hline C. dubliniensis & $0.55-1.0$ & $0.78-1.0$ \\
$(\mathrm{n}=18)$ & mean $=0.71^{\mathrm{a}}$ & mean $=0.96^{\mathrm{b}}$ \\
C. albicans & $0.5-0.85$ & $0.44-0.63$ \\
$(\mathrm{n}=30)$ & mean $=0.65^{\mathrm{c}}$ & mean $=0.51^{\mathrm{d}}$
\end{tabular}

*Value obtained by dividing the diameter of the colony by the total diameter of the colony plus the translucent halo. $\mathrm{d}>\mathrm{b}(p<0.01) . \mathrm{d}>\mathrm{c}(p<0.01)$

\section{DISCUSSION}

The most studied virulence factors of $C$. dubliniensis have been hydrophobicity, adhesion and those observed by experimental infections ${ }^{20}$.

We noticed that $C$. albicans produced higher amounts of proteinases than $C$. dubliniensis. This finding is divergent from that reported by McCULLOUGH et al. ${ }^{10}$ which suggested that $C$. dubliniensis produced higher levels of proteinase activity than $C$. albicans reference isolates. When studying phylogeny and putative virulence factors of $C$. dubliniensis, GILFILLAN et al..$^{5}$ detected seven genes for secretory aspartyl proteinase (SAP), as occurs in C. albicans, but they did not confirm the findings of McCULLOUGH et al. ${ }^{10}$.

Among the $18 \mathrm{C}$. dubliniensis isolates tested all produced hyaluronidase and chondroitin sulphatase, but these activities were not 
different from those observed with $C$. albicans. Hyaluronidase and chondroitin sulphatase are involved in bacterial virulence and the substracts of these enzymes are among the major constituents of connective tissue and gingival epithelium ${ }^{15}$. Hyaluronidase and chondroitin sulphatase can affect the permeability of epithelium in the intercellular spaces by attacking the intercellular cementing substances of tissue ${ }^{18}$. Because $C$. dubliniensis has been isolated mainly from mouth, we judged important to evaluate these exoenzymes. As far as we know, hyaluronidase and chondroitin sulphatase activities from $C$. dubliniensis are here reported by the first time.

Since there is essentially no free iron in the human host, most pathogens acquire this indirectly from commonly available ironcontaining compounds such as hemoglobin. The enzymes involved in this activity are classified as hemolysins ${ }^{3}$. We have found that onto blood agar medium without $\mathrm{CaCl}_{2}$, the hemolytic activity of $C$. dubliniensis was similar to that of $C$. albicans. However, when $\mathrm{CaCl}_{2}$ $2.5 \%$ was added, the hemolytic activity of $C$. dubliniensis decreased while it increased for $C$. albicans. The hemolytic activity of medically important yeasts like genus Candida and Cryptococcus has been scarcely explored. A complement-mediated hemolysis induced by $C$. albicans was reported by MANNS et al..$^{9}$; LUO et al. ${ }^{8}$ studying 80 Candida isolates representing 14 species reported that $C$. albicans and C. dubliniensis among others showed alpha and beta hemolysis; this was the first study to demonstrate the variable expression profiles of hemolysins by different Candida species. However, LUO et al. ${ }^{8}$ have studied only two isolates of $C$. dubliniensis. The $\mathrm{CaCl}_{2}$ has been included in culture media as Calcium donor in the media proposed by PRICE et al. ${ }^{13}$ and more recently in the media proposed by SLIFKIN ${ }^{16}$, named Tween 80 opacity test. In both methods, after enzymatic activity action on distinct substrates, fatty acids are released and the formation of a calcium complex occurs producing a distinct, well-defined, dense white zone of precipitation around the colony. In the Tween 80 opacity test none of the Candida species showed a halo response when $\mathrm{CaCl}_{2}$ was omitted from the medium ${ }^{16}$. Based on these facts, we supplemented the sugar-enriched sheep blood agar medium with growing $\mathrm{CaCl}_{2}$ concentrations in order to obtain a better reading of the hemolytic activity. In a previous assay we have observed that $\mathrm{CaCl}_{2}$ concentrations $>2.5 \mathrm{~g} \%$ were step by step inhibitory for C. dubliniensis (data not shown). So, we established $\mathrm{CaCl}_{2} 2.5 \mathrm{~g} \%$ as the more elevated concentration that did not inhibit the growth of $C$. dubliniensis and $C$. albicans. In general, our results showed that hemolytic activity of $C$. dubliniensis was inhibited by $\mathrm{CaCl}_{2} 2.5 \mathrm{~g} \%$ but the same concentration stimulated the hemolytic activity of $C$. albicans (Table 2). This finding is consistent with previous studies relating $C$. dubliniensis strains as more susceptible to physical and chemical agents than $C$. albicans ${ }^{1,12}$, ${ }^{17}$. On the other hand, it was not possible to apply this finding as a screening test for differentiation between $C$. albicans and $C$. dubliniensis, because the more elevated $C$. albicans hemolytic activity was not absolute and some strains also showed inhibition.

In conclusion, our results suggest that $C$. dubliniensis seems to be less virulent than $C$. albicans because proteinase, the major putative virulence factors, was less expressed or absent. In addition, hyaluronidase, chondroitin sulphatase as well as hemolytic activity are virulence factors less studied and their importance requires new and more rigorous studies.

\section{RESUMO}

\section{Atividade enzimática e hemolítica de Candida dubliniensis}

C. dubliniensis é uma levedura oportunista que, embora já tenha sido isolada de vários sítios anatômicos é, com maior frequência, encontrada na boca de pacientes infectados pelo HIV. Embora tenham sido realizados numerosos estudos sobre a epidemiologia e filogenia, seus fatores de virulência como atividade exoenzimática e atividade hemolítica, são, ainda, pouco conhecidos. Neste estudo comparou-se a atividade in vitro de proteinase, hialuronidase, condroitin sulfatase e atividade hemolítica de 18 cultivos de $C$. dubliniensis com 30 cultivos de $C$. albicans, todos isolados de pacientes com SIDA. Foi evidenciada maior atividade de proteinase em $C$. albicans em relação a $C$. dubliniensis $(p<0,05)$. Todos os isolados de $C$. dubliniensis evidenciaram atividade de hialuronidase e condroitin-sulfatase de forma similar ao observado com $C$. albicans $(p>0,05)$. Constatou-se que a atividade hemolítica foi influenciada pelo $\mathrm{CaCl}_{2}$; em sua ausência não foram observadas diferenças na atividade hemolítica das duas espécies; todavia, ao se agregar $2,5 \%$ de $\mathrm{CaCl}_{2}$, a atividade hemolítica de $C$. dubliniensis foi reduzida enquanto a de $C$. albicans, estimulada $(p<$ $0,05)$.

\section{REFERENCES}

1. ALVES, S.H.; MILÁN, E.P.; LAET SANT'ANA, P. et al. - Hypertonic sabouraud broth as a simple and powerful test for Candida dubliniensis screening. Diagn. Microbiol. infect. Dis., 43: 85-86, 2002.

2. BAUER, D.; MULLER, H.; REICH, J. et al. - Identification of differentially expressed mRNA tests by an improved display technique (DDRT-PCR). Nucleic. Acids Res., 21: 4272-4280, 1993

3. BELANGER, M.; BEGIN, C. \& JACQUES, M. - Lipopolysaccharides of Actinobacillus pleuropneumoniae bind pig hemoglobin. Infect. Immun., 63: 656-662, 1995.

4. DE BERNARDIS, F.; SUlliVAN, P.A. \& CASSONE, A. - Aspartyl proteinases of Candida albicans and their role in pathogenicity. Med. Mycol., 39: 303-313, 2001.

5. GILFILlAN, G.D.; SULLIVAN, D.J.; HAYNES, K. et al. - Candida dubliniensis: phylogeny and putative virulence factors. Microbiology, 144: 829-838, 1998.

6. HANNULA, J.; SAARELA, M.; DOGAN, B. et al. - Comparison of virulence factors of oral Candida dubliniensis and Candida albicans isolates in healthy people and patients with chronic candidosis. Oral Microbiol. Immunol., 15: 238-244, 2000.

7. HUBE, B. \& NAGLIK, J. - Candida albicans proteinases: resolving the mystery of a gene family. Microbiology, 147: 1997-2005, 2001.

8. LUO, G.; SAMARANAYAKE, L.P. \& YAU, J.Y. - Candida species exhibit differential in vitro hemolytic activities. J. clin. Microbiol., 39: 2971-2974, 2001.

9. MANNS, J.M.; MOSSER, D.M. \& BUCKLEY, H.R. - Production of a hemolytic factor by Candida albicans. Infect. Immun., 62: 5154-5156, 1994.

10. McCULLOUGH, M.J.; CLEMONS, K.V. \& STEVENS, D.A. - Molecular and phenotypic characterization of genotypic Candida albicans subgroups and comparison with Candida dubliniensis and Candida stellatoidea. J. clin. Microbiol., 37: 417-421, 1999.

11. MEYER, S.A.; PAYNE, R.W. \& YARROW, D. - Candida Berkhout. In: KURTZMAN, C.P. \& FELL, J.W. The yeasts, a taxonomic study. Amsterdan, Elsevier, 1998. p. 454. 


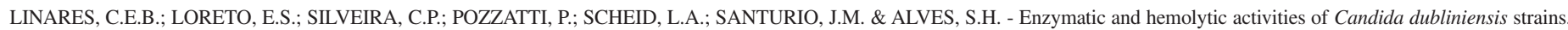
Rev. Inst. Med. trop. Med. S. Paulo, 49(4):203-206, 2007.

12. PINJON, E.; SULLIVAN, D.J.; SALKIN, I.F.; SHANLEY, D. \& COLEMAN, D.C. Simple, inexpensive, reliable method for differentiation of Candida dubliniensis from Candida albicans. J. clin. Microbiol., 36: 2093-2095, 1998.

13. PRICE, M.F.; WILKINSON, I.D. \& GENTRY, L.O. - Plate method for detection of phospholipase activity in Candida albicans. Sabouraudia, 20: 7-14, 1982.

14. RÜCHEL, R.; TEGELER, R. \& TROST, M. - A comparison of secretory proteinases from different strains of Candida albicans. Sabouraudia, 20: 233-244, 1982.

15. SHIMIZU, M.T.; JORGE, A.O.C.; UNTERKIRCHER, C.S.; FANTINATO, V. \& PAULA, C.R. - Hyaluronidase and chondroitin sulphatase production by different species of Candida. J. med. vet. Mycol., 33: 27-31, 1995.

16. SLIFKIN M. - Tween 80 opacity test responses of various Candida species. J. clin. Microbiol., 38: 4626-4628, 2000.
17. SULliVAN, D.J.; WESTERNENG, T.J.; HAYNES, K.A.; BENNETT, D.E. \& COLEMAN, D.C. - Candida dubliniensis sp. nov.: phenotypic and molecular characterization of a novel species associated with oral candidosis in HIV-infected individuals. Microbiology, 141: 1507-1521, 1995.

18. TAM, Y.C.; HARVEY, R.F. \& CHAN, E.C.S. - Chondroitin sulfatase-producing and hyaluronidase-producing oral bacteria associated with periodontal disease. J. Canad. dent. Ass., 48: 115-120, 1982.

19. TANAKA, W.T.H.; NAKAO, N.; MIKAMI, T. \& MATSUMOTO, T. - Hemoglobin is utilized by Candida albicans in the hyphal form but not yeast form. Biochem. Biophys. Res. Commun., 232 : 350-353, 1997.

20. VILELA, M.M.S.; KAMEI, K.; SANO, A. et al. - Pathogenicity and virulence of Candida dubliniensis: comparison with C. albicans. Med. Mycol., 40: 249-257, 2002.

Received: 18 April 2006

Accepted: 21 March 2007 